[Agr. Biol, Chem., Vol. 35, No. 1, p. 79 85, 1971]

\title{
Studies on Antibiotics Produced by Psychrophilic Microorganisms
}

\author{
Part I. Production of Antibiotics by a Psychrophile, \\ Streptomyces sp. No. $81^{\dagger}$ \\ By Koichi Ogata, Noboru Yoshida, Masahiro OHsugi \\ and Yoshiki TaNI \\ Department of Agricultural Chemistry, Kyoto University, Kyoto \\ Received June 18, 1970
}

\begin{abstract}
A screening for antibacterial antibiotics was carried out with psychrophilic microorganisms. The most active microorganism, a soil actinomycete, was selected and characterized to be a facultative psychrophile, Streptomyces sp. No. 81. This strain was found to produce antibiotic(s) in the culture fluid only at low temperature cultivation below $20^{\circ} \mathrm{C}$ but not at moderate temperature. Mycelial growth at low temperature seemed to be indispensable for the antibiotic production. The antibiotic produced by Streptomyces sp. No. 81 was isolated and characterized. It appeared that the antibiotic had the selective toxicity against several Gram-positive bacteria. From the comparative studies with several known antibiotics, the antibiotic appears to be a new compound derived from the new metabolic routes involving temperature-sensitive mechanisms.
\end{abstract}

Although it has generally been known that microorganisms do not grow and multiply well at low temperature, it has recently become a serious problem that foods and biological materials were spoiled by cold-torelant microorganisms, so-called psychrophiles, during the storage at low temperature. Psychrophiles are widely found in nature, not only in polar regions ${ }^{1 /}$ but also in temperate zones ${ }^{21}$ and in the oceans. ${ }^{3 !}$

Studies on the relationship between cultural temperature and microbial activities have been made by many investigators. ${ }^{4-81}$ But few

† A part of this work was presented at the Annual Meeting of the Agricultural Chemical Society of Japan, Fukuoka, April 4, 1970.

1) R. P. Straka and J. L. Stokes, J. Bacteriol., 80, 622 (1960).

2) J. L. Stokes and M. L. Redmond, Appl. Microbiol., 14, 74 (1966).

3) H. Bedford, Contribs. Can. Biol. and Fisheries, 7, 431 (1933).

4) J. Forster, Centr. Bakteriol. Parasitenk., 2, 337 (1887). attempts have been performed on the fermentative utilization of these microorganisms. ${ }^{91}$ It may be assumed that the low temperature cultivation of psychrophiles leads to the production of the metabolites different from those produced at moderate temperature.

Up to date, antibiotics have been discovered exclusively by the microbial cultivation at moderate temperature but never at low temperature. During the investigation on the low temperature fermentation, ${ }^{10,111}$ the authors

5) J. L. Ingraham and J. L. Stokes, Bacteriol. Rev., 23, 97 (1959).

6) R. Y. Morita and R. D. Haight, Limnol. Oceanogr., 9, 103 (1964).

7) O. P. Hagen, D. J. Kunshner and N. E. Gibbons, Can. J. Microbiol., 100, 813 (1964).

8) N. Y. Sinclair and J. L. Stokes, ibid, 11, 259 (1964).

9) X. Konishi, T. Tochikura and K. Ogata, $J$. Ferment. Technol., 45, 795, 803, 809 (1967).

10) K. Ogata, T. Tochikura, N. Kato and M. Osugi, Agr. Biol. Chem., 33, 704 (1969).

11) K. Ogata, N. Kato, M. Osugi and T. Tochikura, ibid., 33, 711 (1969). 
made attempts to isolate antibiotic-producing psychrophiles from various samples, and obtained some strains of bacteria and actinomycetes.

In this paper, the authors will describe the isolation and characterization of a psychrophilic actinomycete, strain No. 81, which produces antibiotic(s) only at low temperature but not at moderate temperature. The production and some characteristics of the antibiotic shall also be presented.

\section{MATERIALS AND METHODS}

\section{1) Media}

a) Media for isolation of psychrophiles. Krainsky's agar medium which is composed of glucose $10 \mathrm{~g}$, Lasparagine $0.5 \mathrm{~g}, \mathrm{~K}_{2} \mathrm{HPO}_{4} 0.5 \mathrm{~g}$ and agar $20 \mathrm{~g}$ in 1000 $\mathrm{ml}$ of tap water, $\mathrm{pH} 7.0$, was used for the isolation of psychrophilic actinomycetes. Nutrient agar medium which is composed of peptone $10 \mathrm{~g}$, meat extract $10 \mathrm{~g}$, $\mathrm{NaCl} 5 \mathrm{~g}$ and agar $20 \mathrm{~g}$ in $1000 \mathrm{ml}$ of tap water, $\mathrm{pH}$ 7.0 , was used for isolation of psychrophilic bacteria. ZoBell's agar medium which is composed of peptone $5 \mathrm{~g}$, yeast extract $1 \mathrm{~g}, \mathrm{FeSO}_{4} \cdot 7 \mathrm{H}_{2} \mathrm{O} 0.1 \mathrm{~g}$ and agar

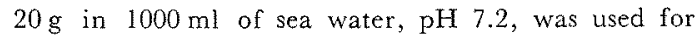
isolation of marine psychrophiles.

b) Media for antibiotic formation. The medium which is composed of soluble starch $15 \mathrm{~g}$, soybean $20 \mathrm{~g}, \mathrm{KNO}_{3} 2 \mathrm{~g}$, yeast extract $2 \mathrm{~g}, \mathrm{NaCl} 3 \mathrm{~g}, \mathrm{~K}_{2} \mathrm{HPO}_{4}$ $2 \mathrm{~g}, \mathrm{KH}_{2} \mathrm{PO}_{4} 0.7 \mathrm{~g}$ and $\mathrm{MgSO}_{4} \cdot 7 \mathrm{H}_{2} \mathrm{O} 0.1 \mathrm{~g}$ in $1000 \mathrm{ml}$ of tap water, $\mathrm{pH} 6.5$, was used for the screening of the antibiotics with actinomycetes. The medium which is composed of glucose $10 \mathrm{~g}$, peptone $10 \mathrm{~g}$, meat extract $5 \mathrm{~g}$ and $\mathrm{NaCl} 5 \mathrm{~g}$ in $1000 \mathrm{ml}$ of tap water, $\mathrm{pH} \mathrm{7.0,}$ was used for the screening of the antibiotics with tererstrial bacteria. The medium which is composed of glucose $10 \mathrm{~g}$, peptone $10 \mathrm{~g}$ and meat extract $5 \mathrm{~g}$ in $1000 \mathrm{ml}$ of sea water, $\mathrm{pH} 7.0$, was used for the screening of the antibiotics with marine bacteria.

c) Medium for antibiotic assay. For the assay of antibiotics, the medium which is composed of peptone $10 \mathrm{~g}$, meat extract $5 \mathrm{~g}$, NaCl $5 \mathrm{~g}$ and agar $20 \mathrm{~g}$ in $1000 \mathrm{ml}$ of tap water, was used. The $\mathrm{pH}$ was adjusted to 7.0 in usual cases, and to 6.0 in the case of assay of the antibiotic produced by Streptomyces sp. No. 81 .

2) Isolation method of psychrophiles
Suspensions of natural materials such as soil, sewage, stream and river water, and sea water, were streaked on the Krainsky's agar plates for actinomycetes, the nutrient agar plates for terrestrial bacteria and the ZoBell's agar plates for marine psychrophiles, respectively. After the incubation at $5^{\circ} \mathrm{C}$ or $15^{\circ} \mathrm{C}$ for 7 to 10 days, the microorganisms grown on the plates were transferred to the agar slants of the same composition. The slants were incubated at $5^{\circ} \mathrm{C}$ or $15^{\circ} \mathrm{C}$ for 5 to 7 days and then stored at $5^{\circ} \mathrm{C}$.

\section{3) Cultivation}

For the investigation of the antibiotic formation, one loopful of organism grown on each agar slant was inoculated into $5 \mathrm{ml}$ of the media mentioned above. The cultivation was carried out on a reciprocal shaker at $5^{\circ} \mathrm{C}$ for about 2 weeks.

\section{4) Microorganisms}

Escherichia coli K-12 IFO 3208, Proteus vulgaris IFO 3167, Bacillus subtilis IFO 3037 and Staphylococcus aureus IFO 3060 were used as test organisms for the assay of antibiotics.

\section{RESULTS AND DISCUSSION}

\section{Isolation of antibiotic-producing psychrophiles}

About 70 pure cultures of actinomycetes, 1000 pure cultures of terrestrial bacteria and

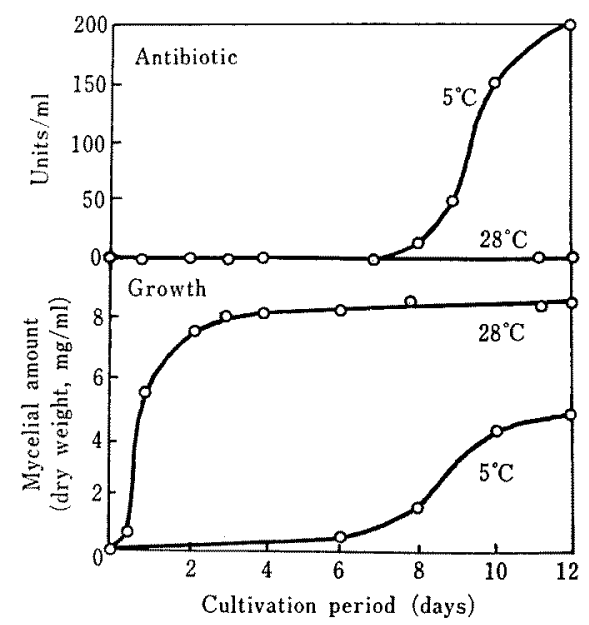

FIG. 1. Growth and Antibiotic Production of Strain No. 81 .

The antibiotic was estimated by agar dilution method with Bacillus subtilis IFO 3037 at $\mathrm{pH} 6.0$. 
Table I. Cultural Properties of Strain No. 81

\begin{tabular}{|c|c|c|c|c|}
\hline Medium & Vegetative mycelium & Aerial mycelium & $\begin{array}{l}\text { Soluble } \\
\text { pigment }\end{array}$ & Remarks \\
\hline Czapek's agar & Spreading, white & $\begin{array}{l}\text { Good, powdery, yellowish } \\
\text { white }\end{array}$ & None & \\
\hline Krainsky’s agar & Good, grayish white & $\begin{array}{l}\text { Abundant, powdery, pink- } \\
\text { ish white to gray }\end{array}$ & None & \\
\hline Ca-malate agar & $\begin{array}{l}\text { Good spreading, yellowish } \\
\text { white }\end{array}$ & Abundant, powdery, white & None & \\
\hline $\begin{array}{l}\text { Starch-ammonium } \\
\text { agar }\end{array}$ & $\begin{array}{l}\text { Good spreading, brownish } \\
\text { white }\end{array}$ & $\begin{array}{l}\text { Abundant, powdery, yel- } \\
\text { lowish white }\end{array}$ & None & \\
\hline Bouillon agar & $\begin{array}{l}\text { Good spreading, pinkish } \\
\text { white }\end{array}$ & Abundant, powdery, white & None & \\
\hline Starch agar & Moderate, gray & Scanty, powdery, white & None & Weak hydrolysis \\
\hline Glucose-Czapek & Poor, spreading, gray & Poor, gray & None & \\
\hline Glucose-bouillon & $\begin{array}{l}\text { Abundant, penetrating, } \\
\text { brown }\end{array}$ & Abundant, white & None & \\
\hline Litmus milk & Moderate, gray & Moderate, green to white & & $\begin{array}{l}\text { Alkaline, rapid } \\
\text { peptonization, } \\
\text { weak coagulation }\end{array}$ \\
\hline Cellulose solution & None & None & None & \\
\hline Gelatin stab & $\begin{array}{l}\text { Penetrating into the medi- } \\
\text { um, gray }\end{array}$ & Moderate, gray to white & None & Liquefaction \\
\hline Potato plug & $\begin{array}{l}\text { Elevated,abundant, yel- } \\
\text { lowish white }\end{array}$ & Abundant, grayish white & & \\
\hline
\end{tabular}

The strain No. 81 was incubated on each medium at $28^{\circ} \mathrm{C}$ for 4 days.

600 pure cultures of marine bacteria capable of growing at $5^{\circ} \mathrm{C}$, were isolated from natural materials. The antibacterial activity against Gram-positive or -negative bacteria was detected in the cultured broth of one seventh of actinomycetes isolated and one tenth of terrestrial and marine bacteria isolated. Most of them, however, showed stronger antibacterial activity by the cultivation at $28^{\circ} \mathrm{C}$. The significant antibacterial activity was obtained by the cultivation of an actinomycete, strain No. 81 , at $5^{\circ} \mathrm{C}$ but not at $28^{\circ} \mathrm{C}$ (Fig. 1). Then, the strain No. 81 was employed in the following experiments.

\section{Taxonomical studies on the isolated actinomycete,} strain No. 81

Morphological and cultural properties. The vegetative mycelia of the strain developed well on the most media used (Table I). On various media, it formed abundant aerial mycelia of about $1 \mu$ in width which developed

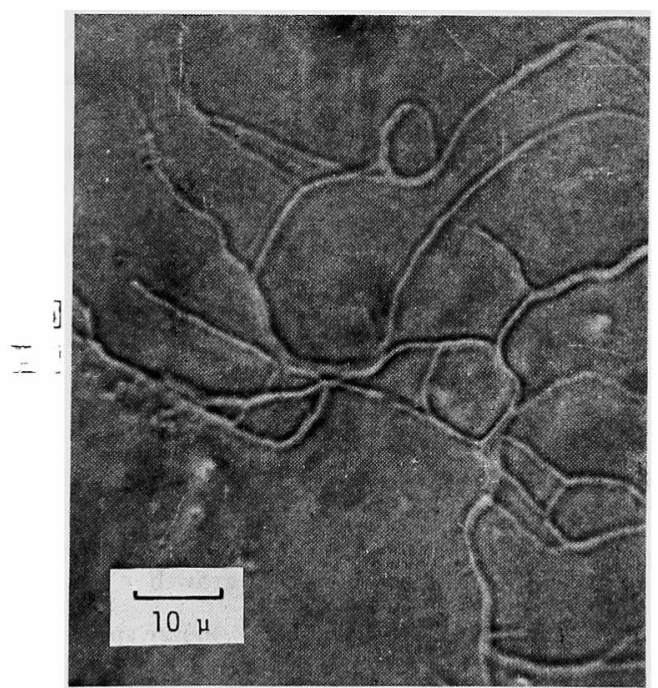

FIG. 2. Microscopic Photograph of Strain No. 81.

into many straight or flexious branches (Fig. 2). Tips of aerial mycelia bore conidial spore chains. The spores were cylindrical or rec- 


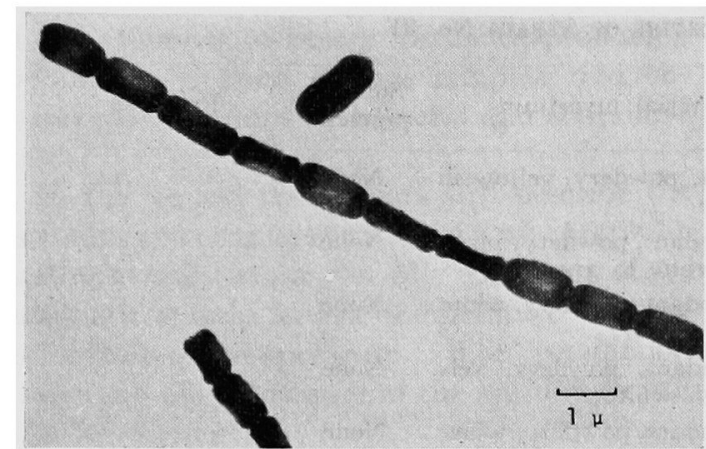

FIG. 3. Electronmicrograph of Conidia of Strain No. $81 . \quad(2,500 \times 4)$

tangular and $0.8-1.0 \mu \times 1.5 \mu$ in size. The spore surface was smooth under electron-microscopy. (Fig. 3).

Physiological properties. Physiological properties of the strain are summarized in Table II. The organism utilized the most of carbohydrates tested.

Growth temperature. As shown in Table II, the strain grew between $0^{\circ} \mathrm{C}$ and $37^{\circ} \mathrm{C}$. The optimum temperature was near $28^{\circ} \mathrm{C}$. It was also observed that no growth occurred above
Table II. Physiological Properties of Strain No. 81

$\begin{array}{ll}\text { Chromogenesis } & \text { Negative } \\ \text { Gelatin liquefaction } & \text { Positive } \\ \text { Action on milk } & \text { Alkaline } \\ & \text { Rapid peptonization } \\ & \text { Weak coagulation } \\ & \text { Positive } \\ \mathrm{H}_{2} \mathrm{~S} \text { formation } & \text { Negative } \\ \text { Indole formation } & \text { Positive } \\ \mathrm{NH}_{3} \text { formation } & \text { Positive } \\ \text { Nitrate reduction } & \text { Negative } \\ \text { Methyl red test } & \text { Positive } \\ \text { Urease activity } & \text { Positive } \\ \text { Catalase activity } & \text { Positive } \\ \text { Starch hydrolysis } & \text { Negative } \\ \text { Cellulolytic activity } & \text { Facultative psychrophilic, } \\ \text { Temperature range } & 0^{\circ} \mathrm{C} \sim 37^{\circ} \mathrm{C}\end{array}$

$37^{\circ} \mathrm{C}$. According to the description by Stokes ${ }^{121}$ based on optimum growth temperature, it seemed that the organism should be classified in a facultative psychrophile.

From these results, it was concluded that this strain belongs to the genus Streptomyces, according to the description in the Bergey's Mannual, 7 th ed. ${ }^{131}$ The comparative studies

Table III. EFfect of Temperature on the Growth and Antibiotic

Production of Streptomyces sp. No. 81

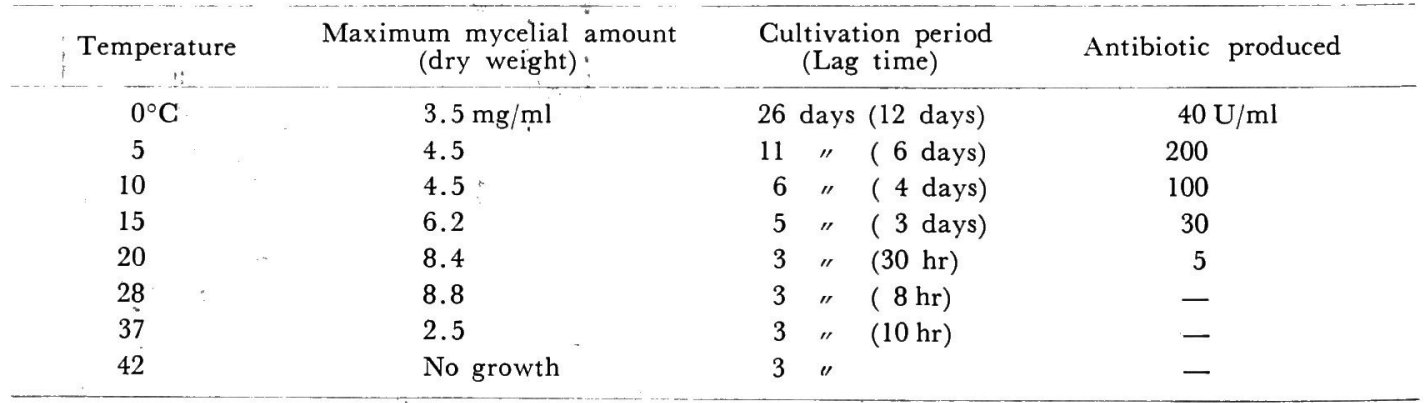

One loopful spores of Streptomyces sp. No. 81 were inoculated into test tubes containing $5 \mathrm{ml}$ of sterile starch-soybean medium, and incubated on a shaker at each temperature. Mycelial dry weight and antibacterial activity were estimated periodically. The antibiotic was estimated as described in Fig. 1.

12) J. L. Stokes, "Recent Progress in Microbiology," VIII, ed. by N. E. Gibbons, Univ. Toronto Press, Toronto, 1962, p. 187.
13) R. S. Breed, E. G. D. Murray and N. R. Smith, "Bergey's Mannual of Determinative Bacteriology," 7th ed., The Williams and Wilkins Co., 1957. 
among the known species in the genus suggested that the tested strain was closely related to Streptomyces griseus. However, the former differed from the latter in a few characteristics such as growth temperature, and then was tentatively named as Streptomyces sp. No. 81.

Effect of temperature on the growth and antibiotic production

The temperature range, in which the strain No. 81 could grow and produce the antibiotic(s), was investigated by cultivating the organism at various temperatures (Table III). The growth and its rate were increased with increased temperature. The antibiotic was produced by the cultivation below $20^{\circ} \mathrm{C}$ but not above $20^{\circ} \mathrm{C}$. The activity of the antibiotic in the cultured broth reached a maximum value after 11 days cultivation at $5^{\circ} \mathrm{C}$ and then gradually decreased. It was also recognized that the organism showed a good growth and produced considerable quantity of the antibiotic even at $0^{\circ} \mathrm{C}$.

\section{Effect of temperature shift on the antibiotic pro- duction}

An attempt was made to shift the temperature from $28^{\circ} \mathrm{C}$ to $5^{\circ} \mathrm{C}$ during the cultivation of the organism at the following three points: 1) at the beginning of macroscopical multipli-

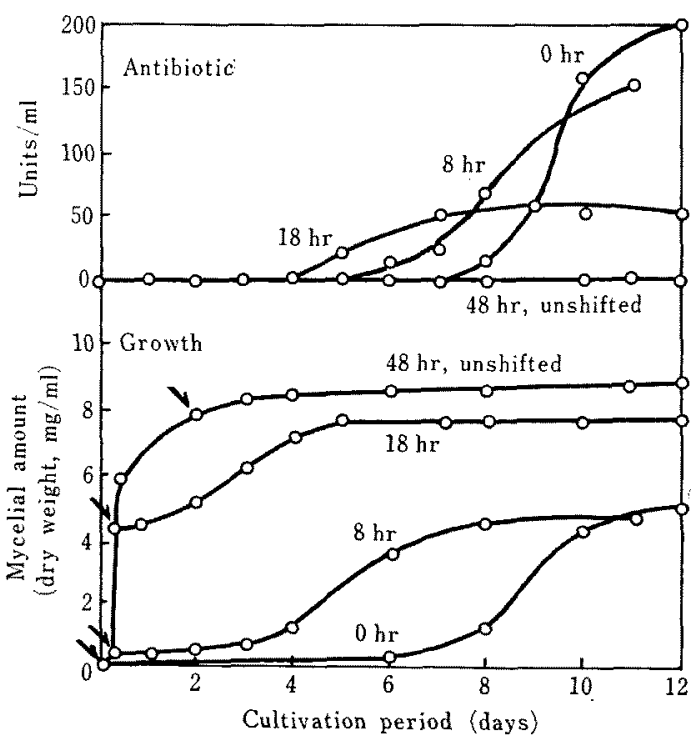

FIG. 4. Effect of Temperature Shift from $28^{\circ} \mathrm{C}$ to $5^{\circ} \mathrm{C}$ on the Growth and Antibiotic Production of Streptomyces sp. No. 81 .

Cultivation temperature was shifted from $28^{\circ} \mathrm{C}$ to $5^{\circ} \mathrm{C}$ at the times indicated by the arrows $(0,8$, 18 and $48 \mathrm{hr}$ ). The antibiotic was estimated as described in Fig. 1 .

Table IV. Degradative Activity of Intact Mycelium of Sireptomyces sp.

No. 81 on ITS OWN ANTIBIOTIC

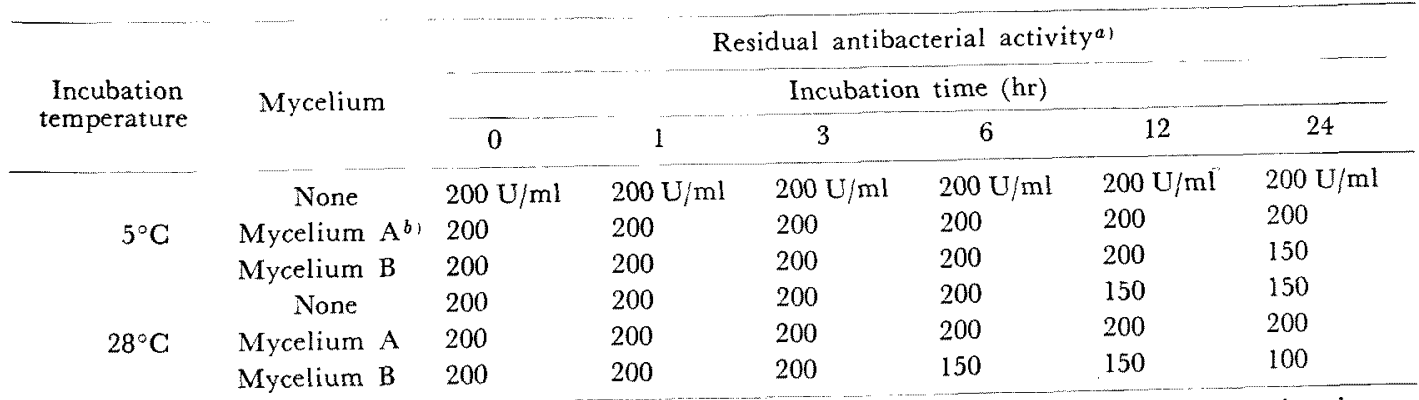

Each reaction mixture consisted of 500 units of the antibiotic, $250 \mu$ moles of potassium phosphate buffer, $\mathrm{pH} 6.5$, and $12.5 \mathrm{mg}$ of intact mycelium in a final volume of $2.5 \mathrm{ml}$. Incubation was carried out with shaking at $5^{\circ} \mathrm{C}$ and $28^{\circ} \mathrm{C}$, respectively.

a) The antibiotic was estimated as described in Fig. 1.

b) The mycelium $\mathrm{A}$ and $\mathrm{B}$ were obtained by the cultivation of Streptomyces sp. No. 81 at $5^{\circ} \mathrm{C}$ for 12 days, and at $28^{\circ} \mathrm{C}$ for 4 days, respectively. 
cation after $8 \mathrm{hr}$ incubation; 2) in the midst of the exponential growth after $18 \mathrm{hr}$ incubation; and 3) at the end of the exponential growth after $48 \mathrm{hr}$ incubation. Preincubation of the organism at $28^{\circ} \mathrm{C}$ hastened the growth and shortened the over-all cultivation period, but decreased the yield of the antibiotic. When cultivation was carried out at $28^{\circ} \mathrm{C}$ for $48 \mathrm{hr}$ and then the temperature was shifted to $5^{\circ} \mathrm{C}$, the antibiotic production no longer proceeded (Fig. 4). This may indicate that the multiplication of the organism at $5^{\circ} \mathrm{C}$ is indispensable for the antibiotic production.

Followingly, an attempt was made to investigate whether the mycelium grown at $28^{\circ} \mathrm{C}$ possessed the stronger activity of destroying the antibiotic accumulated than that grown at $5^{\circ} \mathrm{C}$ with intact mycelia. The each mycelium cultivated at $5^{\circ} \mathrm{C}$ for 12 days and at $28^{\circ} \mathrm{C}$ for 4 days was aseptically harvested, washed and transferred into the potassium phosphate buffer solution, $\mathrm{pH}$ 6.5, which contained 200 units of the antibiotic per $\mathrm{ml}$, and then incubated on a reciprocal shaker at $5^{\circ}$ and $28^{\circ} \mathrm{C}$, respectively. The antibacterial activity was periodically assayed. As shown in Table IV, the mycelia grown at $28^{\circ} \dot{\mathrm{C}}$ as well as at $5^{\circ} \mathrm{C}$ possessed a weak or no degradative activity to the antibiotic. Moreover, the antibiotic was recognized to be heat-stable because the antibacterial activity in the cultured broth was not reduced by boiling for $3 \mathrm{~min}$.

From these results, it seemed that the biosynthetic mechanisms of the antibiotic might be temperature-sensitive ones.

\section{Isolation of the antibiotic}

The antibiotic produced by Streptomyces sp. No. 81 was more stable at acidic $\mathrm{pH}$ range and showed the stronger antibacterial activity in the assay media in which $\mathrm{pH}$ was adjusted to 6.0 than those adjusted to 7.0 or 8.0 (Table V). According to the general consideration that antibiotics which show strong activity at acidic $\mathrm{pH}$ range are acidic compounds, the
TABle V. Relation betWeen pH and Minimal INHIBITORY CONCENTRATION OF THE GROWTH oF TEST ORganisms

\begin{tabular}{|c|c|c|c|}
\hline \multirow{3}{*}{ Organism } & \multicolumn{3}{|c|}{$\mathrm{MIC}(\mathrm{U} / \mathrm{ml})^{a}$} \\
\hline & \multicolumn{3}{|c|}{$\mathrm{pH}$} \\
\hline & 6 & 7 & 8 \\
\hline Bacillus subtilis IFO 3037 & 1 & 2 & 5 \\
\hline Bacillus megaterium NIH B12 & 0.5 & 1 & 2 \\
\hline Staphylococcus aureus IFO 3060 & 5 & 10 & 20 \\
\hline Micrococcus lysodeikticus IFO 3333 & 1 & 2 & 5 \\
\hline Sarcina lutea IAM 1099 & 2 & 3 & 5 \\
\hline
\end{tabular}

a) Agar dilution streak method was employed.

The $\mathrm{pH}$ of the medium was adjusted to 6,7 and 8 , respectively. The antibiotic was estimated as described in Fig. 1.
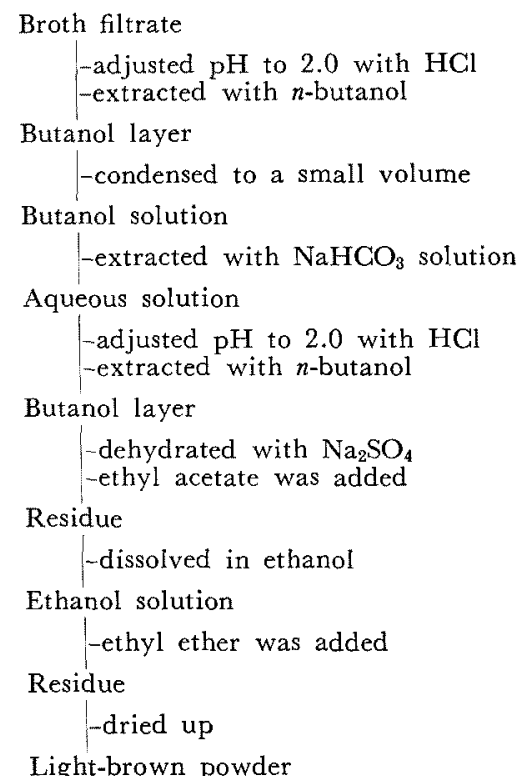

FIG. 5. Isolation and Purification of the Antibiotic Produced by Streptomyces sp. No. 81 .

antibiotic produced by this organism is thought to be an acidic one. The isolation procedure of the antibiotic was comparable to that used for other acidic antibiotics as outlined in Fig. 5.

Twenty liters of the filtrate of the cultured broth was adjusted to $\mathrm{pH} 2.0$ with hydrochloric acid and extracted three times with 4 liters of 
Table VI. Antimicrobial Activity of the Antibiotic Produced BY Streptomyces sp. No. 81

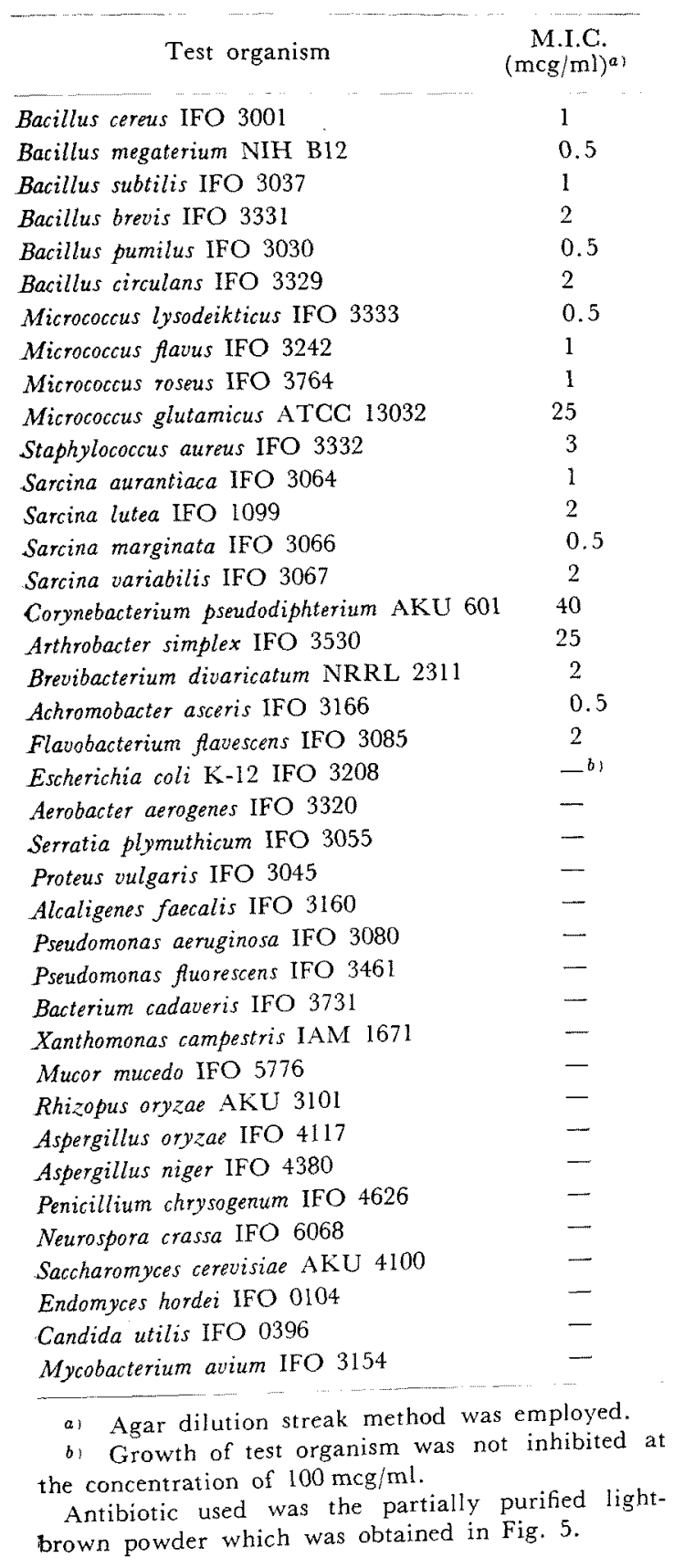

$n$-butyl alcohol followed by reextraction with $500 \mathrm{ml}$ of dilute sodium bicarbonate solution. Condensed aqueous solution was again adjusted to $\mathrm{pH} 2.0$ and extracted with $100 \mathrm{ml}$ of $n-$ butyl alcohol. Then, several parts of ethylacetate were added to the alcohol solution to give brown crude powder of the antibiotic. The crude powder was dissolved in small amount of ethyl alcohol and then precipitated with ethyl ether. The partially purified lightbrown powder showed antibacterial activity more than 1000 units per mg against Bacillus subtilis IFO 3037.

Improved isolation and purification procedures shall be shown in later paper.

\section{Biological properties}

The biological activity was studied by using the partially purified antibiotic, obtained as shown in Fig. 5 possessing antibacterial activity more than 1000 units per $\mathrm{mg}$ against Bacillus subtilis IFO 3037 . The antibacterial and antifungal spectra obtained by the agar dilution streak method are shown in Table VI. As shown in this table, the antibiotic produced by Streptomyces sp. No. 81 showed a strong inhibitory activity against Gram-positive bacteria, but a weak or no activity against Gramnegative bacteria, yeasts and fungi.

Comparative studies of the antibiotic, including the bioautographies and chemical reactions, indicated that the compound produced by Streptomyces sp. No. 81 differed from several known antibiotics such as tetracyclines, streptomycins, erythromycins, pyrrotin compounds, etc. Assuming that new metabolic reactions involving temperature-sensitive mechanisms may take place for the production of the antibiotics at low temperature, it is likely that the antibiotic produced by Streptomyces sp. No. 81 at low temperature is a new compound.

Acknowledgement. The authors wish to thank Dr. H. Yamada, Research Institute for Food Science, Kyoto University, Kyoto, for his helpful advices. 